\title{
Mapping Surface Cover Using EO-1 Hyperion Data: Ongoing Studies in Arid Environments
}

\author{
David W. Leverington \\ Department of Geosciences \\ Texas Tech University \\ Lubbock, TX 79409
}

\begin{abstract}
The utility of Hyperion images in the discrimination of surface classes is currently being tested at two study areas: 1) eastern Melville Island, Nunavut, Canada; and 2) Big Bend National Park, Texas. Hyperion unmixing results for the Melville Island study area effectively depict fractional surface cover, although the abundance images of several classes contain background values that locally overestimate surface exposure. At Big Bend National Park, separation of classes through Hyperion unmixing has been hindered by the relatively indistinct weathering characteristics of several key sedimentary units. Ongoing research efforts include experimentation with hyperspectral classification approaches that entail reduction of Hyperion data dimensionality through the combination of spectral bands.
\end{abstract}

Keywords- geology; desert regions; spectroscopy

\section{INTRODUCTION}

In the discrimination of surface cover classes, hyperspectral data offer improved potential for class separation relative to broad-band multispectral data. Though EO-1 Hyperion data do not have optimal signal-to-noise characteristics, the data are notable in providing spectral coverage across almost 200 functional bands that collectively span the visible, nearinfrared, and short-wave infrared ranges of the electromagnetic spectrum. The effectiveness of Hyperion images in the discrimination of lithological and other surface cover classes is currently being tested at Melville Island, Canada, and Big Bend National Park, Texas (Fig.1).

\section{HYPERION IMAGES}

The Hyperion sensor [1] is one of several instruments mounted on the EO-1 spacecraft, which was launched in 2000 and is now operating on an extended mission in partnership between the United States Geological Survey and the National Aeronautics and Space Administration. Hyperion collects optical data in 242 spectral bands in the visible, near-infrared, and short-wave infrared. Of these channels, 198 are unique and characterized by sufficient signal-to-noise to be used as a basis for surface mapping. Spectral coverage spans the range of $\sim 0.4-2.4 \mu \mathrm{m}$, with spectral resolutions of individual bands of $\sim 10 \mathrm{~nm}$. The Hyperion sensor operates with a swath width of $7.6 \mathrm{~km}$ and a pixel size of $30 \times 30 \mathrm{~m}$. Hyperion is characterized by inferior signal-to-noise relative to AVIRIS and other sensors with comparable spectral resolution [2-4], but nevertheless represents an important landmark in the development of spaceborne remote-sensing technologies. Hyperion data have been successfully used to support a diverse range of activities including the mapping of rock and mineral classes [3,5], and the discrimination of vegetation classes [6-8].

\section{STUDY AREAS}

\section{A. Melville Island, Nunavut, Canada}

The Melville Island study area is located in the Canadian territory of Nunavut. Bedrock units in the study area consist mainly of late-Paleozoic clastic and carbonate formations of the

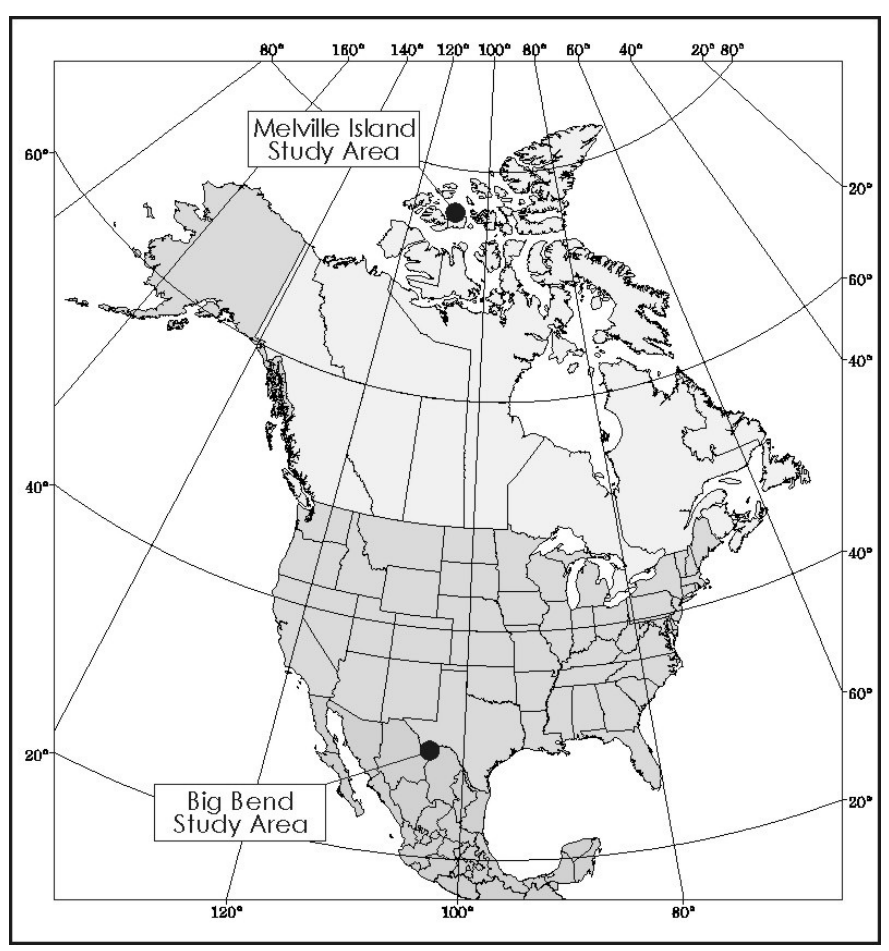

Figure 1. Melville Island is part of the Queen Elizabeth Islands, an archipelago that comprises the landmass of the Canadian High Arctic. The western side of this archipelago is classified as a polar desert. Big Bend National Park is located in Brewster County, southwest Texas, and forms part of the Chihauhuan Desert. 
Sverdrup Basin [9]. Also present are Silurian carbonates of the shelf province of the Franklinian Mobile Belt, and a nearvertical Cretaceous gabbro dike. Elevations in the region mainly range from 0 to $\sim 200 \mathrm{~m}$ above sea level, and northdipping cuesta landforms dominate the terrain. Ridge-forming sedimentary units include the Bjorne Formation, the Degerböls Formation, and the Great Bear Cape Formation. The most common surface material in the study area consists of weathered and frost-shattered felsenmeer, which mantles parent bedrock units [10]. Melville Island is located within the zone of continuous permafrost, and the low annual precipitation of the region $(\sim 10 \mathrm{~cm})$ has led to its classification as a polar desert [11]. Vegetation cover is less than $10 \%$ over much of the study area and mainly consists of barrens communities comprised of varieties including Saxifraga oppositifolia (purple saxifrage), Salix arctica (arctic willow), and grasses [12]. Dense tundra communities also exist in the study area, but are of relatively restricted extent.

\section{B. Big Bend National Park, Texas}

Big Bend National Park is located in Brewster County, southwest Texas. The park forms part of the Chihuahuan Desert, which extends across parts of Texas, New Mexico, Arizona, and northern Mexico. An experimental transect has been defined across the western part of the park on the basis of the wide diversity of geological and botanical classes contained within its boundaries [13]. This transect extends northward from the Rio Grande, across Rattlesnake, Bee, and Tule mountains, to Maverick and Dogie mountains in the northwestern part of the park. Elevations within the transect span a range of $\sim 300 \mathrm{~m}$ (with peak absolute elevations of $\sim 1150 \mathrm{~m}$ ), though relief in the nearby Chisos Mountains exceeds $1000 \mathrm{~m}$. A wide range of material types is exposed across the transect, including those related to sedimentary units of the Aguja, Pen, Javelina, and Black Peaks formations, sedimentary and volcanic units of the Chisos and Canoe formations, Tertiary volcanic units, and alluvium. The extent of vegetation cover within the transect varies widely, ranging from full cover to virtually no cover. Especially common varieties of vegetation in the study area include creosote, mesquite, willow, sotol, agave, rosaceae, cacti, yuccas, and a diverse range of grasses.

\section{SPECTRAL CHARACTERISTICS OF SURFACE MATERIALS}

The spectral characteristics of lithological classes exposed within the two study areas were generalized from materials collected in situ (Figs.2-3) [13,14]. The spectra of representative whole-rock samples were measured in a laboratory setting using an Analytical Spectral Devices (ASD) FieldSpec® 3 spectrometer equipped with a contact probe. For each class, reflectance values were determined at $\sim 10 \mathrm{~nm}$ intervals between 350 and $2500 \mathrm{~nm}$.

The spectral properties of some sedimentary units in the Melville Island study area are comparable (e.g., the Great Bear Cape limestone and the Tingmisut Inlier dolostone) (Fig.2). The most spectrally distinct classes of the region include the dark-red-weathering materials of the Assistance Formation mudstone, the red-weathering materials of the Canyon Fiord Formation sandstone, and the low-reflectance materials that comprise the gabbro dike [14]. Among the most distinct absorption features associated with materials in the Melville Island study area are those at $\sim 1000 \mathrm{~nm}$ and less than $600 \mathrm{~nm}$, related to the presence of ferric iron. Water-related absorption features are located at 1400 and $1900 \mathrm{~nm}$. Carbonate absorption features at $\sim 2300 \mathrm{~nm}$ characterize the limestone and dolostone classes, as well as clastic rocks with carbonate cements. Absorption features at $\sim 2200 \mathrm{~nm}$, related to the presence of clay minerals such as kaolinite or smectite, are also present in the spectra of several rock classes.

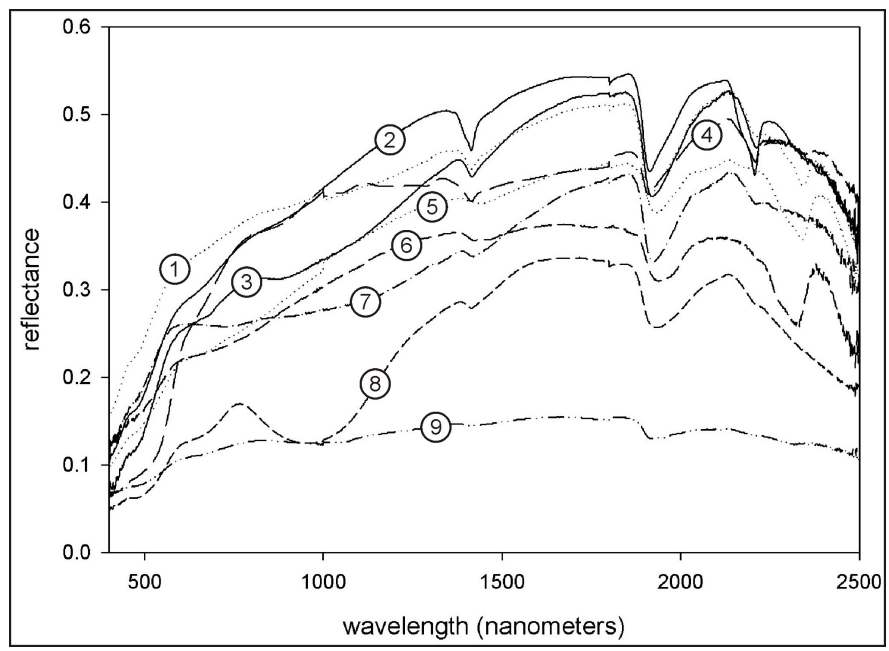

Figure 2. Reflectance characteristics of representative whole-rock samples of lithological units in the Melville Island study area [14]. Individual spectra are labelled as follows: 1 - Degerböls Fm limestone; 2 - Great Bear Cape Fm limestone; 3 - Tingmisut Inlier dolostone; 4 - Canyon Fiord Fm sandstone; 5 - Sabine Bay Fm sandstone; 6 - Bjorn Fm sandstone; 7 - Trold Fiord Fm sandstone; 8 - Assistance Fm mudstone; 9 - gabbro intrusion.

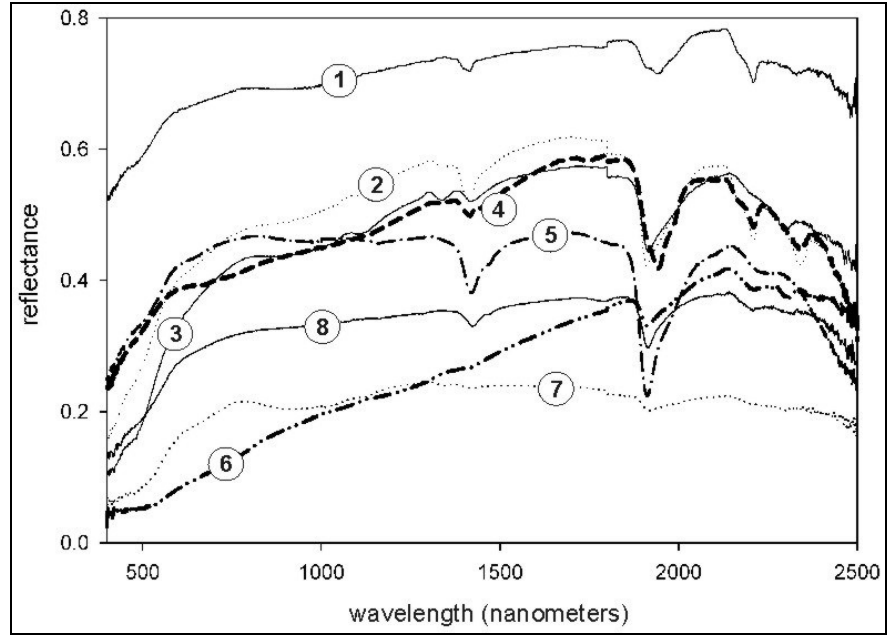

Figure 3. Reflectance characteristics of representative whole-rock samples of lithological units in the Big Bend National Park study area [13]. Individual spectra are labeled as follows: 1 - evaporite crust; 2 - Javelina Fm tanweathering sandstone; 3 - Pen Fm tan-weathering shale; 4 - Aguja Fm tanweathering sandstone; 5 - Chisos Fm ash; 6 - Chisos Fm dark mafic unit; 7 Chisos Fm tan-weathering basalt; 8 -Tertiary syenodiorite. 
As with the surface materials of eastern Melville Island, the materials of the Big Bend National Park study area are characterized by spectral troughs indicative of the presence of ferric iron, carbonate minerals, and clay minerals (Fig.3). The spectral properties of several sedimentary end members of interest in the study area (Pen Formation shale, Aguja Formation sandstone, Javelina Formation sandstone) are variable across the park and substantially overlap within the study transect. Some end members, including evaporite deposits and mafic igneous units, instead have relatively distinct spectral properties.

The presence of non-geological classes including snow and vegetation cover complicate discrimination of lithological classes on Melville Island and in Big Bend National Park. The state of surface materials is depicted for several field sites in Figs.4-6.

\section{UNMIXING AND CLASSIFICATION RESULTS}

Hyperion unmixing images for the Melville Island study area effectively depict the complexity of the fractional cover of key end members, and complement the simplified depictions provided by geological maps (Fig.7) [14]. However, Hyperion abundance images overestimate surface exposure for classes including limestone, sandstone, and snow. Such overestimations are likely related both to overlap in the spectral properties of classes (caused by similarities in the mineralogical and weathering characteristics of geological classes) and the relatively low signal-to-noise characteristics of the Hyperion sensor. Classes most clearly distinguished in the Melville Island fraction images include snow, green vegetation, and sedimentary classes with distinct weathering characteristics (sandstones of the Canyon Fiord Formation and mudstones of the Assistance Formation). The utility of Hyperion unmixing results is superior to that of results generated through the unmixing of Landsat Thematic Mapper datasets [14]. However, the information content of separate neural network classifications generated from Thematic
Mapper imagery is comparable to that of the Hyperion-derived fraction images.

At the Big Bend National Park study area, a wide range of surface cover classes can be distinguished through unmixing of Hyperion data. Classes most clearly distinguished in generated fraction images include green vegetation and igneous units of mafic composition [13]. Discrimination of several sedimentary units of interest is hindered by the relatively indistinct weathering characteristics of associated materials (Fig.3). Improved characterization of the reflectance properties of these materials, and of vegetation classes distributed across the imaged transect, may ultimately allow for improved separation of sedimentary units in the study area.

Though the Hyperion unmixing images generated for both the Melville Island and Big Bend National Park study areas provide useful information regarding the nature of fractional surface cover (e.g., allowing for quantitative separation between the spectral contributions of lithological classes and discontinuous vegetation cover), the overall information content of these images is not in all cases superior to that of images generated using simpler methods involving per-pixel classification of Landsat Thematic Mapper data. Refinement of the techniques and inputs used in unmixing exercises may allow for improvement in the utility of unmixing results.

\section{ONGOING WORK}

Ongoing research efforts include investigation of the utility of fraction images for the quantitative characterization of the lithological compositions of alluvial fans in Big Bend National Park. Efforts also include experimentation with hyperspectral classification approaches that entail reduction of Hyperion data dimensionality through the combination of spectral bands. Such approaches offer the potential to reduce noise in Hyperion data while providing an improved basis for per-pixel classifications relative to established broadband multispectral image types such as Landsat Thematic Mapper.

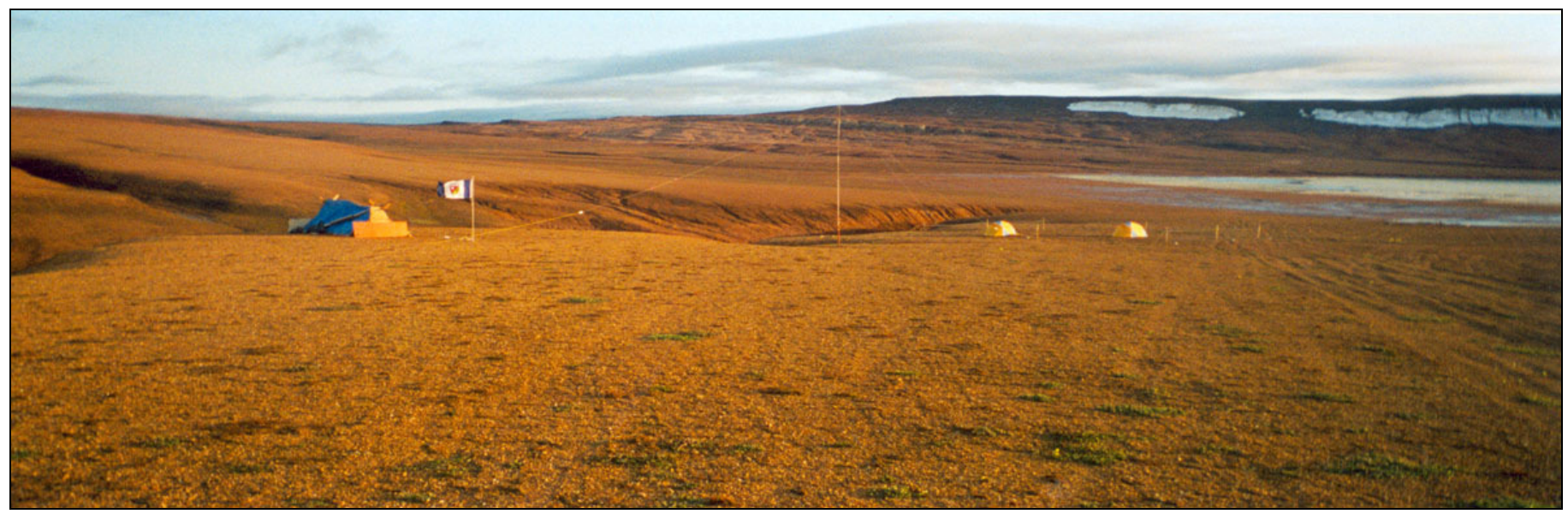

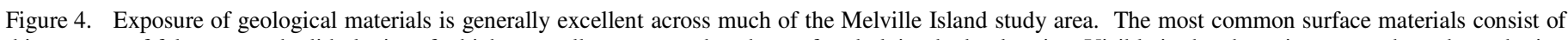

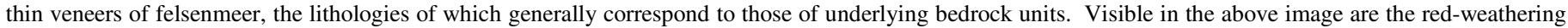

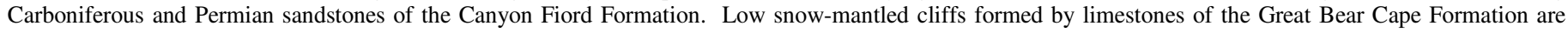
visible at right. A Hyperion image was acquired across this area on July 21, 2002. 


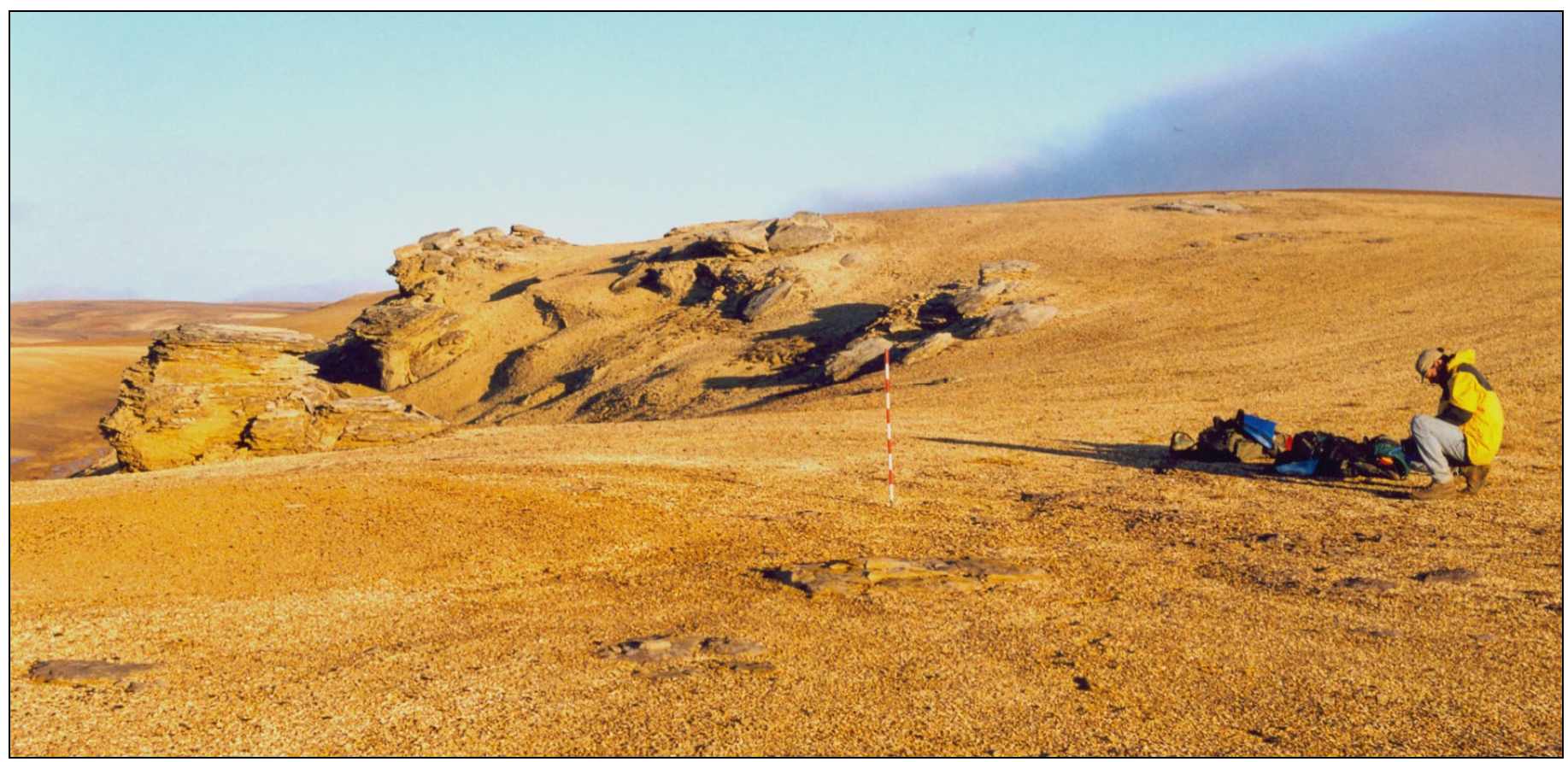

Figure 5. Exposed Permian sandstones of the Sabine Bay Formation, Melville Island. Felsenmeer extends across much of this area, with extensive bedrock exposures mainly confined to the scarps of cuestas (as depicted here at center-left). The extent of vegetation cover on Sabine Bay Formation materials is typically minimal.

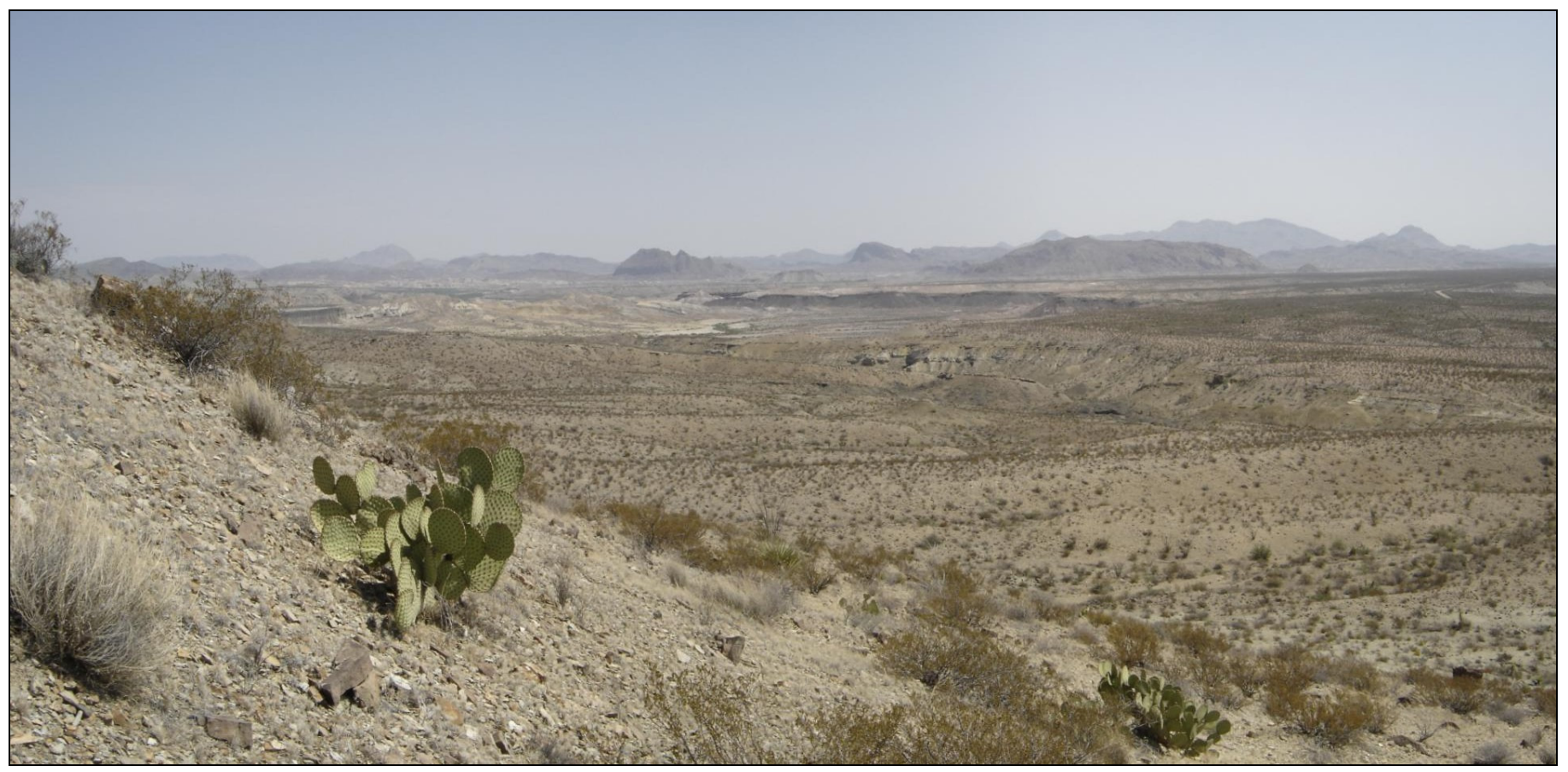

Figure 6. Cretaceous clastic and carbonate units of the Rattlesnake Mountains region, Big Bend National Park. Unconsolidated weathering products mantle much of the area, with bedrock exposures most common along steep slopes. Vegetation cover is generally greatest along the floors of large arroyos. A Hyperion image was acquired across this area on July 23, 2007. 


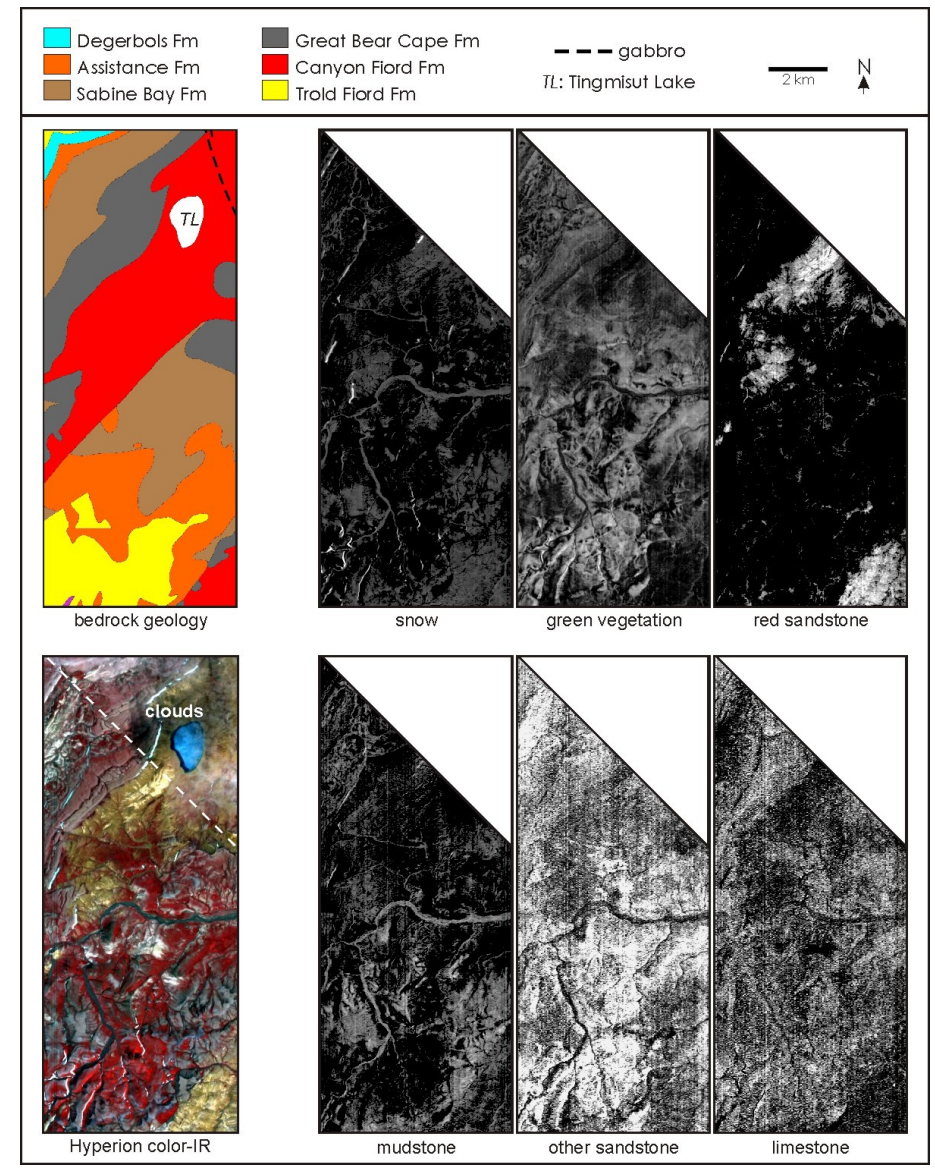

Figure 7. Left: generalized bedrock geology [9] and a Hyperion color-infrared image of part of the Melville Island study area. Right: corresponding unmixing results produced from Hyperion-derived reflectance data for six end members [14] (several of the end members described in Fig.2 are not exposed in this part of the study area). The numeric values of fractional-component images range from 0.0 (black) to 1.0 (white). Unmixing results in the immediate vicinity of Tingmisut Lake were rendered invalid by clouds present at the time of imaging.

\section{REFERENCES}

[1] J. Pearlman, P,. Barry, C. Segal, J. Shepanski, D. Beiso, and S. Carman, "Hyperion, a space-based imaging spectrometer," IEEE Transactions on Geoscience and Remote Sensing, vol. 41, 2003, pp.1160-1173.

[2] B.E. Hubbard, J.K. Crowley, and D.R. Zimbelman, "Comparative alteration mineral mapping using visible to shortwave infrared (0.4$2.4 \mu \mathrm{m})$ Hyperion, ALI, and ASTER imagery," IEEE Transactions on Geoscience and Remote Sensing, vol. 41, 2003, pp.1401-1410.

[3] F. Kruse, J. Boardman, and J. Huntington, "Comparison of airborne hyperspectral data and EO-1 Hyperion for mineral mapping," IEEE Transactions on Geoscience and Remote Sensing, vol. 41, 2003, pp.1388-1400.

[4] B.E. Hubbard, and J.K. Crowley, "Mineral mapping on the ChileanBolivian Altiplano using co-orbital ALI, ASTER and Hyperion imagery: Data dimensionality issues and solutions," Remote Sensing of Environment, vol. 99, 2005, pp. 173-186.

[5] R. Gersman, E. Ben-Dor, M. Beyth, D. Avigad, M. Abraha, and A. Kibreab, "Mapping of hydrothermally altered rocks by the EO-1 Hyperion sensor, northern Danakil Depression, Eritrea," International Journal of Remote Sensing, vol. 29, 2008, pp.3911-3936.

[6] B. Datt, T.R. McVicar, T.G. van Niel, D.L.B. Jupp, and J.S. Pearlman, "Preprocessing EO-1 Hyperion hyperspectral data to support the application of agricultural indexes," IEEE Tranactions on Geoscience and Remote Sensing, vol. 41, 2003, pp.1246-1259.

[7] E. Ramsey III, A. Rangoonwala, G. Nelson, R. Ehrlich, and K. Martella, "Generation and validation of characteristic spectra from EO-1 Hyperion image data for detecting the occurrence of the invasive species, Chinese tallow," International Journal of Remote Sensing, vol. 26, 2004, pp.1611-1636.

[8] F. Tsai, E.-K. Lin, and K. Yoshino, "Spectrally segmented principle component analysis of hyperspectral imagery for mapping invasive plant species," International Journal of Remote Sensing, vol. 28, 2007, pp.1023-1039.

[9] J.C. Harrison, Melville Island and Adjacent Smaller Islands, Canadian Arctic Archipelago, District of Franklin, Northwest Territories, Geological Survey of Canada, Map 1844A, scale 1:250,000, 1995.

[10] D.A. Hodgson, J.S. Vincent, and J.G. Fyles, Quaternary Geology of Central Melville Island, Northwest Territories, Geological Survey of Canada, Paper 83-16, 1984.

[11] J.B. Maxwell, The Climate of the Canadian Arctic Islands and Adjacent Waters, vol. 1, Atmospheric Environment Service, Climatological Studies 30, Toronto, 1980.

[12] S.A. Edlund, "The distribution of plant communities on Melville Island, Arctic Canada," in The Geology of Melville Island, Arctic Canada, R.L. Christie and N.J. McMillan, Eds., Geological Survey of Canada, Bulletin 450, 1994.

[13] D.W. Leverington, "Discrimination of geological end members using Hyperion imagery: Preliminary results, Big Bend National Park, Texas," IEEE International Geosciences and Remote Sensing Symposium, Boston, Massachusetts, 2008.

[14] D.W. Leverington, "Discrimination of sedimentary lithologies using Hyperion and Landsat TM data: A case study at Melville Island, Canadian High Arctic," International Journal of Remote Sensing, in press. 